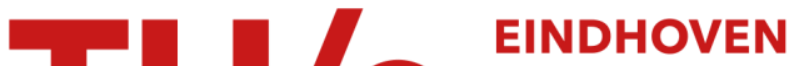 UNIVERSITY OF TECHNOLOGY
}

\section{RF photogun for external injection of electrons in a laser wakefield accelerator}

\section{Citation for published version (APA):}

Stragier, X. F. D., Geer, van der, S. B., Wiel, van der, M. J., \& Luiten, O. J. (2011). RF photogun for external injection of electrons in a laser wakefield accelerator. In Proceedings of the Conference SPIE Optics and Optoelectronics, 18-21 April 2011, Prague, Czech Republic

\section{Document status and date:}

Published: 01/01/2011

\section{Document Version:}

Publisher's PDF, also known as Version of Record (includes final page, issue and volume numbers)

\section{Please check the document version of this publication:}

- A submitted manuscript is the version of the article upon submission and before peer-review. There can be important differences between the submitted version and the official published version of record. People interested in the research are advised to contact the author for the final version of the publication, or visit the $\mathrm{DOI}$ to the publisher's website.

- The final author version and the galley proof are versions of the publication after peer review.

- The final published version features the final layout of the paper including the volume, issue and page numbers.

Link to publication

\section{General rights}

Copyright and moral rights for the publications made accessible in the public portal are retained by the authors and/or other copyright owners and it is a condition of accessing publications that users recognise and abide by the legal requirements associated with these rights.

- Users may download and print one copy of any publication from the public portal for the purpose of private study or research.

- You may not further distribute the material or use it for any profit-making activity or commercial gain

- You may freely distribute the URL identifying the publication in the public portal.

If the publication is distributed under the terms of Article 25fa of the Dutch Copyright Act, indicated by the "Taverne" license above, please follow below link for the End User Agreement:

www.tue.nl/taverne

Take down policy

If you believe that this document breaches copyright please contact us at:

openaccess@tue.nl

providing details and we will investigate your claim. 


\section{Connecting minds. Advancing light.}

SPIE is the international society for optics and photonics
SEARCH:

Enter Keywords

Conferences + Exhibitions

\section{Conferences \& Exhibitions} Calendar

- Optics + Optoelectronics 2011

\section{Chair Invitation}

Conferences

Special Forums and Events Exhibition

Exhibitor Services

Author/Presenter Information Chair/Committee Information Hotel + Travel

Registration
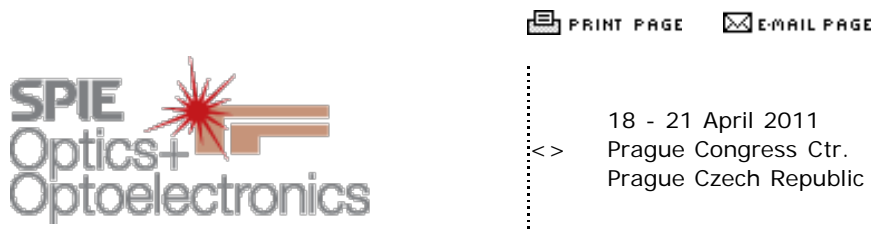

\section{Your search for "stragier" returned:}

1 Scheduled events

0 Exhibitors + Products

Sort by: $\odot$ Relevance $\bigcirc$ Date

Show abstracts

1 items $\mathbf{1}-\mathbf{1}$

\section{RF photogun for external injection of electrons in a laser wakefield} accelerator

Paper 8079A-31 of Conference 8079A

Date: Tuesday, 19 April 2011

Time: $17: 10-17: 30$

Author(s): G. J. H. Brussaard, X. F. D. Stragier, Bas van der Geer, Marnix J. van der Wiel, Jom Luiten, Technische Univ. Eindhoven (Netherlands)

No abstract available

\section{Search Program}

To refine your search, check all that apply

$\square$ Oral \& Poster Presentations

$\square$ Special Forums \& Events

Exhibitors \& Products

All Days

Pit View My Schedule HI Customize your program 